\title{
Determination of Optimal Added-Levels of Inuloprebiotics for Promotion of Growing Performance in Broiler Chickens
}

\author{
Byung-Sung Park* \\ Department of Animal Biotechnology, Kangwon National University, Chuncheon 200-701, Korea
}

Received January 25, 2011 /Accepted May 23, 2011

\begin{abstract}
The present study furthered this research by determining the optimal level of inuloprebiotics derived from Korean Jerusalem artichoke to promote growth in broiler chickens. On hatch day, 320 male Ross 308 broilers were randomly allotted to four groups for a 35-day feeding regimen. The groups were a control (no supplementation), diet supplementation with antibiotics (8 ppm avilamycin), supplementation with 200 ppm inuloprebiotics, and supplementation with $250 \mathrm{ppm}$ inuloprebiotics. Body weight and feed intake were comparably high in the two inuloprebiotics groups, and exceeded the values for the control and antibiotics groups. Body weight and feed intake was higher in chickens fed the antibiotics supplemented diet, compared to controls. There were significant differences among treatment groups. Feed conversion ratio during total experimental periods was significantly high in the control group compared to the inuloprebiotics-fed groups, but no significant difference was evident using antibiotics or inuloprebiotics dietary supplementation. Carcass weight, dressing percentage, and weight of breast and thigh muscle were significantly higher for inuloprebiotics-fed chickens, compared with control and antibiotic-fed chickens. Inuloprebiotics concentration was not significant, while antibiotics-fed chickens displayed significantly higher values than control chickens. Abdominal fat was significantly reduced $(19.08 \%-23.30 \%)$ and blood immunoglobulin and the weight of the thymus and Bursa of Fabricius were significantly increased in chickens receiving inuloprebiotics-supplemented feed, compared to control and antibiotics fed groups. In the lower intestine, the viable counts of beneficial bacteria (Bifidobacteria and Lactobacillus) were significantly increased and counts of harmful bacteria (Escherichia coli and Salmonella sp.) were significantly decreased in the presence of the inuloprebiotics, compared to control and antibiotic. The present results support $200 \mathrm{ppm}$ as an optimal level of Korean Jerusalem artichoke-derived inuloprebiotics as a dietary supplement to improve growth in broiler chickens.
\end{abstract}

Key words : Inuloprebiotics, performance, immnuoglobulin, caecum microflora

\section{서 론}

항생제 내성균의 출현은 심각한 사회적 문제가 되었으며 친환경 유기축산이 시작되면서 사료용 항생제의 철회가 강화 되었다. 공장집약형 축산업에서 사료용 항생제를 사용하지 않 을 경우 발생할 수 있는 피해와 손실을 줄이고 지속적인 가축 의 생산성 향상을 위해 항생제를 대체할 수 있는 천연물질로 부터 항균성장촉진제의 개발이 시작되었다 $[6,21,33]$.

프리바이오틱스는 동물의 상부소화관 효소에 의해 가수 분해되지 않고 대장으로 이동되어서 장 내 미생물 특히 bifidobacteria의 선택적인 성장, 미생물의 활력 또는 미생물의 제한된 균수를 자극하여서 숙주동물에게 유익한 영향을 주 는 비분해성 식이성분이다[10]. 프리바이오틱스는 비피더스 균의 활성효과를 갖는 항균성장촉진제임과 동시에 면역조 절제로서 어린 동물의 설사를 방지하고 가축의 성장을 촉진

*Corresponding author

Tel : +82-33-250-8615, Fax : +82-251-7719

E-mail : bspark@kangwon.ac.kr
하는 물질이다[25].

이눌린[27], fructooligosaccharide [40], isomalto-oligosaccharides [41], Essential oil [14] 등은 대표적인 프리바리오 틱스이다. 특히 이눌린은 과당이 $\beta(2 \rightarrow 1)$ glycosidic bond로 연결된 선형 과당중합체로써 동물의 위액과 소화효소에 의하 여 분해되지 않고 $80 \%$ 이상이 대장에 도달하여 장내 미생물 발효기질로서 이용되어 장내 유해균주의 성장을 억제하고 유 익한 균주인 비피도박테리아의 성장을 선택적으로 자극하여 브로일러의 성장을 촉진시키는 것으로 알려져 있다[7,26,28]. 그러나 이눌린은 공기 중 유통에 의한 변성 및 소화관 상부에 서 맹장으로의 이동 시 낮은 통과율이 지적되고 있기 때문에 이를 개선하기 위해서 미세캡슐화된 이눌로프리바이오틱스 제조기술이 보고되었다[22,24].

저자는 선행연구에서 한국산 돼지감자로부터 추출한 이눌 린의 in vitro 항균활성을 조사한 결과, 대조군과 비교할 때 이눌린 첨가군에서 유익균인 Bifidobacterium longum, Bifidobacterium bifidum, Lactobacillus acidophilus, Lactobacillus casei 균주의 성장률은 높았으나, Streptococcus aureus, 
Clostridium perfringens 유해균주의 증식은 억제되었으며, 이눌 린으로부터 제조한 이눌로프리바이오틱스를 섭취한 브로일 러의 맹장에서 비피도박테리아의 선택적인 증식과 동시에 흥 선지수 및 IgG의 증가[22], 이눌로프리바이오틱스를 섭취한 브로일러가 항생제 첨가구에 비해서 우수한 증체효과를 갖는 다고 하였으며 브로일러 생산에 관한 경제성을 고려해 볼 때 이눌로프리바이오틱스의 최적 첨가수준 결정에 관한 추가적 인 연구가 필요함을 지적하였다[23].

본 연구는 선행연구에서 확립된 국산 돼지감자로부터 추출, 제조한 이눌로프리바이오틱스의 브로일러 성장능력 개선을 위한 항균성장촉진제로서 활용을 위한 후속연구로써 사료 내 최적 첨가수준을 조사하기 위하여 수행하였다.

\section{재료 및 방법}

\section{이눌로프리바이오틱스의 조제}

이눌린(평균 중합도 26)은 국산 돼지감자로부터 열수, 냉각 추출방법에 의해 추출, 동결건조하여 분말화하였다[9]. 항산화 제로써 비타민 a-tocopheryl acetate $15 \mathrm{ppm}$ 과 추출한 이눌린 을 따뜻한 물과 함께 혼합하여 고압균질기(T25 Basic, IKA, German)를 이용하여 고압균질화하였다. 얻어진 고압균질물 과 닭의 소화 상부기관 $\mathrm{pH}$ 에서 안정하며 맹장에서 용해되는 특성을 지닌 장용피복재로서 슈레테릭(Sureteric, Colorcon, $\mathrm{UK})$ 을 9:1 (w/w)로 혼합, 미세피복해서 항균성 이눌로프리바 이오틱스를 제조하였다[22,24].

\section{실험동물 및 실험설계}

실험동물을 포함한 과학적인 절차는 유럽실험동물취급면 허 기준에 의한 과학적이고 윤리적인 규정을 따랐으며[32] 강 원대학교 동물실험윤리위원회(IACUC, Institutional Animal Care and Use Committee of Kangwon National University) 로부터 실험승인을 얻었다. 부화 당일 로스계통(Ross 308)의 브로일러 수컷 320 수를 4 처리구 $\times 4$ 반복(반복 당 20 수)으로 완 전임의배치하였다. 4 개의 실험처리구는 1) 대조구, 2) 항생제 (Avilamycin) $8 \mathrm{ppm}$, 3) 이눌로프리바이오틱스 $200 \mathrm{ppm}, 4$ ) 이눌로프리바이오틱스 $250 \mathrm{ppm}$ 첨가구로 구분하였다. 이눌 로프리바이오틱스의 첨가수준은 선행연구[22] 결과를 기초로 하여 선정하였다.

\section{실험사료 및 사양관리}

실험사료는 옥수수, 대두박 위주로 배합하였으며 NRC 사 양표준[20]을 기초로 하여 브로일러의 영양소 요구량을 충족 할 수 있도록 하면서 동일한 조단백질과 대사에너지를 함유토 록 하였으며 옥수수의 량을 줄여서 항생제와 이눌로프리바이 오틱스의 첨가수준을 조절하였다(Table 1). 즉, 프리믹스 $\mathrm{kg}$ 당 이눌로프리바이오틱스를 각각 $20 \mathrm{~g}, 25 \mathrm{~g}$ 함유하게 조절한 후
Table 1. Composition of experimental basal diets for broiler chickens (\% as-fed)

\begin{tabular}{|c|c|c|}
\hline \multirow[b]{2}{*}{ Ingredient } & \multicolumn{2}{|c|}{ Experimental basal diets } \\
\hline & $\begin{array}{c}\text { Starter } \\
(0-21 \text { days })\end{array}$ & $\begin{array}{c}\text { Grower } \\
\text { (22-35 days) }\end{array}$ \\
\hline Yellow corn ground & 52.00 & 50.00 \\
\hline Soybean meal, $44 \% \mathrm{CP}$ & 34.00 & 25.00 \\
\hline Corn gluten meal & 4.70 & 5.70 \\
\hline Wheat meal & - & 10.00 \\
\hline Soybean oil & 5.00 & 5.00 \\
\hline Limestone & 1.25 & 1.25 \\
\hline Dicalcium phosphate & 1.70 & 1.70 \\
\hline Sodium chloride & 0.25 & 0.25 \\
\hline DL-Met, $50 \%$ & 0.30 & 0.30 \\
\hline L-Lys $\mathrm{HCl}, 78 \%$ & 0.30 & 0.30 \\
\hline Trace mineral premix ${ }^{1)}$ & 0.34 & 0.34 \\
\hline Vitamin premix ${ }^{2}$ & 0.16 & 0.16 \\
\hline Total & 100 & 100 \\
\hline \multicolumn{3}{|l|}{ Calculated values 3 ) } \\
\hline $\mathrm{ME}, \mathrm{kcal} / \mathrm{kg}$ & 3,100 & 3,150 \\
\hline $\mathrm{CP}, \%$ & 22.00 & 20.00 \\
\hline Lys, \% & 1.32 & 1.15 \\
\hline Met, \% & 0.52 & 0.50 \\
\hline Met+Cys, \% & 0.78 & 0.73 \\
\hline $\mathrm{Ca}, \%$ & 1.00 & 0.90 \\
\hline Available P, \% & 0.45 & 0.40 \\
\hline
\end{tabular}

${ }^{1)}$ Supplied per kilogram of diet: Fe, $80 \mathrm{mg}$; Zn, $80 \mathrm{mg}$; Mn, 70 $\mathrm{mg}$; $\mathrm{Cu}, 7 \mathrm{mg}$;, $1.20 \mathrm{mg}$; Se, $0.30 \mathrm{mg}$; Co, $0.70 \mathrm{mg}$.

${ }^{2)}$ Supplied per kilogram of diet: vitamin A (retinyl acetate), 10,500 IU; vitamin $\mathrm{D}_{3}, 4,100 \mathrm{IU}$; vitamin E (DL-a-tocopheryl acetate), $45 \mathrm{mg}$; vitamin $\mathrm{K}_{3}, 3.0 \mathrm{mg}$; thiamin, $2.5 \mathrm{mg}$; riboflavin, $5 \mathrm{mg}$; vitamin $\mathrm{B}_{6}, 5 \mathrm{mg}$; vitamin $\mathrm{B}_{12}, 0.02 \mathrm{mg}$; biotin, $0.18 \mathrm{mg}$; niacin, $44 \mathrm{mg}$; pantothenicacid, $17 \mathrm{mg}$; folic acid, $1.5 \mathrm{mg}$.

${ }^{3)}$ Calculated values from NRC (1994).

기초사료 내 $0.10 \%$ 를 첨가하여 이눌로프리믹스의 수준을 200 $\mathrm{ppm}$ 과 $250 \mathrm{ppm}$ 으로 조절하였다. 표준환경상태(밀도 10 마리 $/ \mathrm{m}^{2}$ )하에서 부화 후 35 일 동안 사육하였으며 각 펜은 왕겨 깔짚을 바닥 $10 \mathrm{~cm}$ 높이로 깔아주었다. 브로일러는 전기(0-21 일)와 후기(22-35 일)로 구분하여 실험사료를 물과 함께 무제 한 급여하였다. 사육실의 온도는 입추당일에서 3 일까지 $33^{\circ} \mathrm{C}$ 로 유지하였고 그 다음부터 주당 $2 \sim 3^{\circ} \mathrm{C}$ 씩 낮췄으며 22 일부터 $25^{\circ} \mathrm{C}$ 로 유지하였다. 상대습도는 $70 \%$ 로 유지하였고 24 시간 연 속조명을 실시하였으며 자동환기시스템을 이용하여 일일 3-5 회 환기를 해주었다.

\section{사양성적 및 도체특성}

브로일러의 사양성적으로서 사료섭취량, 증체량 및 사료요 구율은 3 주령과 5 주령으로 구분하여 측정하였다. 사료 요구율 은 각 해당 기간 중의 사료섭취량을 증체량으로 나누어 계산 하였다. 사육종료 후 각 처리구별로 평균체중에 가까운 닭으 로써 16 수씩(반복 펜 당 4 수씩)을 선별하여 실험동물 안락사 
권장[3]에 따라서 목비틀기에 의해서 스트레스를 주지 않고 안정적으로 희생하였다. 도체율은 생체중에 대한 도체중(깃 털, 혈액, 머리, 다리 및 내장을 제외한 무게)의 비율로써 계산 하였으며, 첫 번째 목뼈에서 머리를 잘라냈고 무릎 정강이 부 위에서 다리를 잘라냈다. 가슴살과 닭 껍질을 포함한 다리살 의 무게는 도체중에 대한 무게비율로서 각각 계산하였고, 간, 근위, 복강지방, 면역기관(흥선, 비장, $\mathrm{F}$ 낭)의 무게는 생체중에 대한 비율로서 나타냈다. 복강지방은 복강과 근위주변의 지방 을 모두 취해서 측정하였다.

\section{혈청 면역물질}

실험종료일 에 각 처리구 당 12 수씩(반복펜 당 3수씩)을 임 의로 선정하여 목정맥으로부터 plain tube (Greine Co Ltd, Australia)를 이용해서 $1 \mathrm{ml}$ 혈액을 채취하였다. 원심분리기 (RC-3, SORVALL Co., USA)를 이용하여 $4^{\circ} \mathrm{C}, 15$ 분간 3,000 $\mathrm{rpm}$ 에서 원심분리하여 혈청을 얻었다. 액화질소가스를 이용 해서 혈청을 급속동결 한 이후에 분석 시까지 $-20^{\circ} \mathrm{C}$ 냉동보관 하였다. ELISA (enzyme-linked immunosorbent assay, Bethyl laboratories., Inc., USA)에 의해서 면역물질을 측정하였다 [18]. 항체의 량은 IgG (chicken IgG ELISA quantitation set, E30-104), IgA (chicken IgA ELISA quantitation set, E30-103) 및 IgM (chicken IgM ELISA quantitation set, E30-102)을 이용 하여 각각 반응시킨 다음 microplate reader (Molecular Devices, Inc., New York, USA)에 의해서 $450 \mathrm{~nm}$ 에서 흡광도 를 측정해서 계산하였다.

\section{맹장 미생물}

실험종료일에 안락사 이후 처리구 당 브로일러 16수씩(반 복 펜 당 4수씩)을 선정하여 무균적인 방법으로 맹장을 채취하 였다. 맹장은 AnaeroGen sachets (Oxoid, Hampshire, UK)가 갖춰진 Sealed anaerobic jars (Oxoid, Basingstoke, UK)에서 분석할 때까지 혐기적인 상태로 유지하였다. 균질화한 맹장 내용물 $1.0 \mathrm{~g}$ 과 멸균된 인산완충식염수(Phosphorus buffered saline; PBS 0.1 M, pH 7.0) $9 \mathrm{ml}$ 를 혼합해서 10배로 1차 희석한 다음에 멸균된 혐기성 생리식염수로써 일련의 희석을 계속하 였다. 상기의 절차는 Anaerobic chamber $(5 \%$ hydrogen, $5 \%$ $\mathrm{CO}_{2}$, balanced nitrogen)에서 혐기적인 상태하에서 진행하였 다. 희석된 시료 $\left(10^{2} \sim 10^{7}\right)$ 를 멸균된 평판배지에 각각 $100 \mu 1$ 씩 분주하여 미생물 배양을 실시하였다. 사용한 배지는 Lactobacillus SPP. (MRS agar, Oxoid, Basingstoke, UK); Bifidobacterium SPP. (bifidobacterium selective agar, BIM-25 medium) [19]; Salmonella (SS agar Difco, CM0099); Escherichia coli (McConkey Purple agar)이었다. Salmonella 와 Escherichia coli는 $37^{\circ} \mathrm{C}$ 에서 24시간 호기배양 하였고, Lactobacillus SPP.와 Bifidobacterium SPP.는 AnaeroGen sachets가 갖춰진 Sealed anaerobic jars를 이용한 혐기적인 상태하에서 $37^{\circ} \mathrm{C}$ 로 각각 48 ,
72시간 정치배양 한 후 미생물카운터로써 colony의 수를 조사 하였다. 계수는 맹장내용물 g당 균수(CFU, colony-forming unit/g of fresh cecal content)로써 상용로그를 취하여 제시하 였다.

\section{통계분석}

얻어진 모든 자료는 SAS software의 GLM procedure를 사 용하여 분산분석을 실행한 후 Duncan"s multiple range test 에 의해서 $95 \%$ 신뢰수준에서 통계적인 유의차 $(\beta<0.05)$ 를 검정 하였다[30].

\section{결과 및 고찰}

\section{성장능력}

부화 당일부터 35 일 동안 이눌로프리바이오틱스를 섭취한 브로일러의 성장능력은 Table 2에 나타냈다. 브로일러의 체중 과 사료섭취량은 사양단계별 및 전체 실험기간 중 이눌로프리 바이오틱스 첨가구가 대조구, 항생제 첨가구와 비교할 때 유 의하게 높았다. 이눌로프리바이오틱스 $200 \mathrm{ppm}, 250 \mathrm{ppm}$ 사 이의 차이는 없었으나 항생제 첨가구는 대조구에 비해서 높았 으며 통계적인 유의차가 인정되었다. 사료요구율은 전기 동안 대조구가 항생제 및 이눌로프리바이오틱스 첨가구에 비해서 유의하게 높았으나 항생제 첨가구와 이눌로프리바이오틱스 첨가구 간 유의차는 없었다. 후기에는 대조구, 항생제 첨가구 가 이눌로프리바이오틱스 첨가구와 비교할 때 유의하게 높았 으나, 대조구와 항생제 첨가구 그리고 이눌로프리바이오틱스 $200 \mathrm{ppm}$ 과 $250 \mathrm{ppm}$ 첨가구 사이의 통계적인 유의차는 없었 다. 전체 실험기간 동안 대조구는 이눌로프리바이오틱스 첨가 구와 비교할 때 유의하게 높았으나 대조구와 항생제 첨가구 그리고 항생제 첨가구와 이눌로프리바이오틱스 첨가구 사이 의 통계적인 유의차는 없었다.

특히 여기서 발견한 중요한 점은 이눌로프리바이오틱스 $200 \mathrm{ppm}$ 이상에서는 체중 증가가 더 이상 나타나지 않는 일정 한 수준의 안정점(Plateau)를 갖는다는 사실이었다. Park과 Park [22]은 이눌로프리바이오틱스 $300 \mathrm{ppm}, 450 \mathrm{ppm}$ 을 섭취 한 브로일러의 성장능력은 항생제 첨가구에 비해서 우수하지 만 서로간 차이가 없었으며 경제성을 고려할 때 보다 낮은 수준에서 최적 첨가수준을 조사할 필요성을 제시하였다. 그 후속연구로서 진행한 본 결과와 Park과 Park [22]의 결과를 종합해 볼 때 $200 \mathrm{ppm}$ 이상의 수준 즉 250, 300, $450 \mathrm{ppm}$ 에서 나타난 체중증가는 서로 비슷하였기 때문에 브로일러의 증체 효과를 높이기 위한 이눌로프리바이오틱스의 최적첨가수준 은 $200 \mathrm{ppm}$ 이 적절할 것으로 판단되었다.

이눌로프리바이오틱스의 처리구에서 브로일러의 증체량이 높았던 점은 이눌로프리바이오틱스 처리구의 맹장에서 건강 에 유익한 Lactobacillus 와 Bifidobacteria의 성장이 촉진되었고 
Table 2. Growth performance of broilers fed the experimental diets for 35 days

\begin{tabular}{|c|c|c|c|c|c|}
\hline \multirow[b]{2}{*}{ Days } & \multicolumn{4}{|c|}{ Treatment groups } & \multirow[b]{2}{*}{$\mathrm{SEM}^{1)}$} \\
\hline & Control & $\begin{array}{c}\text { Antibiotics } \\
8 \mathrm{ppm}\end{array}$ & $\begin{array}{c}\text { Inuloprebiotics } \\
200 \mathrm{ppm}\end{array}$ & $\begin{array}{c}\text { Inuloprebiotics } \\
250 \mathrm{ppm}\end{array}$ & \\
\hline \multicolumn{6}{|c|}{--- Body weight gain, g -------- } \\
\hline $0-21$ & $795^{\mathrm{c}}$ & $837^{\mathrm{b}}$ & $861^{\mathrm{a}}$ & $860^{\mathrm{a}}$ & 6.9785 \\
\hline $22-35$ & $1,008^{\mathrm{c}}$ & $1,068^{\mathrm{b}}$ & $1,143^{\mathrm{a}}$ & $1,140^{\mathrm{a}}$ & 8.9515 \\
\hline $0-35$ & $1,813^{\mathrm{c}}$ & $1,905^{\mathrm{b}}$ & $2,004^{\mathrm{a}}$ & $2,000^{\mathrm{a}}$ & 21.0584 \\
\hline \multicolumn{6}{|c|}{-- Feed intake, g - } \\
\hline $22-35$ & $1,637^{\mathrm{c}}$ & $1,716^{b}$ & $1,772^{\mathrm{a}}$ & $1,778^{\mathrm{a}}$ & 16.1753 \\
\hline $0-35$ & $2,939^{c}$ & $3,063^{b}$ & $3,157^{\mathrm{a}}$ & $3,162^{\mathrm{a}}$ & 25.8917 \\
\hline \multicolumn{6}{|c|}{ - Feed conversion ratio ${ }^{2)}$} \\
\hline $0-21$ & $1.63^{\mathrm{a}}$ & $1.60^{\mathrm{b}}$ & $1.60^{\mathrm{b}}$ & $1.60^{\mathrm{b}}$ & 0.0047 \\
\hline $22-35$ & $1.62^{\mathrm{a}}$ & $1.60^{\mathrm{a}}$ & $1.55^{\mathrm{b}}$ & $1.56^{\mathrm{b}}$ & 0.0126 \\
\hline $0-35$ & $1.62^{\mathrm{a}}$ & $1.60^{\mathrm{ab}}$ & $1.57^{\mathrm{b}}$ & $1.58^{\mathrm{b}}$ & 0.0068 \\
\hline
\end{tabular}

${ }^{1)}$ Standard error of the mean values.

${ }^{2)}$ Feed conversion ratio is feed intake/body weight gain.

${ }^{a, b, c, d}$ Mean values with different superscripts differ significantly $(p<0.05)$.

Table 3. Characteristics of carcass of broilers fed the experimental diets for 35 days

\begin{tabular}{lccccc}
\hline & \multicolumn{5}{c}{ Treatment groups } \\
\cline { 2 - 5 } Item $^{1)}$ & Control & $\begin{array}{c}\text { Antibiotics } \\
8 \text { ppm }\end{array}$ & $\begin{array}{c}\text { Inuloprebiotics } \\
200 \mathrm{ppm}\end{array}$ & $\begin{array}{c}\text { Inuloprebiotics } \\
250 \text { ppm }^{2}\end{array}$ & SEM $^{2}$ \\
\hline Carcass weight, g & $1,305^{\mathrm{c}}$ & $1,403^{\mathrm{b}}$ & $1,450^{\mathrm{a}}$ & $1,465^{\mathrm{a}}$ & 20.6254 \\
Dressing percentage & $71.40^{\mathrm{c}}$ & $72.56^{\mathrm{b}}$ & $73.25^{\mathrm{a}}$ & $73.18^{\mathrm{a}}$ & 0.2077 \\
Breast muscle, \% & $18.65^{\mathrm{c}}$ & $19.24^{\mathrm{b}}$ & $19.78^{\mathrm{a}}$ & $19.80^{\mathrm{a}}$ & 0.1653 \\
Thigh muscle, \% & $16.57^{\mathrm{c}}$ & $17.33^{\mathrm{b}}$ & $18.27^{\mathrm{a}}$ & $18.28^{\mathrm{a}}$ & 0.2022 \\
Gizzard, \% & 1.78 & 1.75 & 1.79 & 1.80 & 0.0271 \\
Liver, \% & 2.88 & 2.90 & 2.87 & 2.90 & 0.0220 \\
Abdominal fat, \% & $1.76^{\mathrm{a}}$ & $1.73^{\mathrm{a}}$ & $1.54^{\mathrm{b}}$ & $1.43^{\mathrm{c}}$ & 0.0587 \\
\hline
\end{tabular}

${ }^{1)}$ Carcass weight relative to live body weight; Breast and thigh muscle weight relative to carcass weight. Gizzard, liver and abdominal fat weight relative to live body weight.

${ }^{2}$ Standard error of the mean values.

${ }^{\mathrm{a}, \mathrm{b}, \mathrm{c}}$ Mean values with different superscripts differ significantly $(p<0.05)$.

(Table 5), 면역기관인 흥선, 비장 및 F낭 무게의 증가로 혈액 면역물질이 높아짐(Table 4)으로써 동물의 건강이 증진되고 사료섭취량을 자극하였기 때문으로 생각할 수 있다. Cetein 등[2]은 프리바오틱스의 면역능력 및 항균활성물질의 증진작 용에 의해서 동물의 건강이 향상되어 증체율이 높아지는 것으 로 보고하였고, Rehman 등[6]은 이눌린의 $\beta(2 \rightarrow 1)$ glycosidic bond는 브로일러의 소화효소에 저항성이 있으며 동물의 장내 건강에 유익한 미생물의 성장을 촉진하고 유해한 미생물의 성장을 억제하는 것으로 보고하여 본 결과를 뒷받침 해준다. 브로일러 사료 내 프리바이오틱스로서 이눌린[28], FOS [31], $\mathrm{IMO}$ [41], 식물 추출물[14]을 급여하였을 때 체중이 증가되었 다는 보고는 본 결과를 지지해준다.

\section{도체특성}

이눌로프리바이오틱스를 섭취한 브로일러에서 조사한 도
체중, 도체율, 가슴살, 다리살, 간, 근위 및 복강지방 무게는 Table 3에 나타내었다. 도체중과 도체율은 이눌로프리바이오 틱스 첨가구가 대조구, 항생제 첨가구에 비해서 유의하게 높 았다. 이눌로프리바이오틱스 $200 \mathrm{ppm}, 250 \mathrm{ppm}$ 첨가구 사이 의 유의차는 없었으나 항생제 첨가구는 대조구에 비해서 유의 하게 높았다. 가슴살, 다리살의 무게는 이눌로프리바이오틱스 첨가구가 대조구, 항생제 첨가구에 비해서 높았고 이눌로프리 바이오틱스 $200 \mathrm{ppm}, 250 \mathrm{ppm}$ 첨가구 사이의 차이는 없었으 나 항생제 첨가구는 대조구와 비교할 때 높은 경향을 보였으 며 각 처리구 사이는 통계적인 유의차가 인정되었다. 근위와 간 무게는 처리구 간 차이가 없었고, 복강지방은 이눌로프리 바이오틱스 첨가구가 대조구, 항생제 첨가구와 비교할 때 유 의하게 낮아졌으나 대조구와 항생제 첨가구 사이의 차이는 나타나지 않았다. 
복강지방의 감소율은 대조구와 비교할 때 이눌로프리바이 오틱스 $200 \mathrm{ppm}, 250 \mathrm{ppm}$ 첨가구에서 각각 19.08\%, 21.97\%, 항생제 첨가구와 비교할 때 이눌로프리바이오틱스 $200 \mathrm{ppm}$, $250 \mathrm{ppm}$ 첨가구에서 각각 $20.45 \%, 23.30 \%$ 낮아져 본 실험에 서 발견한 획기적인 내용이었다. 지질대사에서 혈액지질은 생 체조직으로 이동되어 에너지를 발생하는 데 사용되고 여분의 지질은 복강조직에 축적된다는 점은 널리 알려진 이론이다. 본 연구결과 복강지방이 감소하였던 점은 양계사료에 첨가된 이눌린의 혈액지질 감소작용[37]에 의해 복강조직으로 이동한 지질수준이 낮아진 데 기인한 것으로 생각할 수 있다. 사람과 대부분의 동물실험에서 이눌린은 혈액지질을 낮추는 것으로 알려졌으며 이눌로프리바이오틱스 처리구에서 복강지방이 낮았던 점은 이눌린의 생체 지질감소 기작에 기인한 효과로 볼 수 있다[8,36].

Kok 등[16]은 쥐에게 $10 \%$ oligofructose를 급여했을 때 혈 액 중성지방-VLDL의 유의적인 감소를 보고하였으며, Davidson등[4]은 고콜레스테롤 혈증 사람에게 치커리 이눌린 을 급여하였을 때 총콜레스테롤과 LDL-C 함량이 유의적으로 낮아졌다고 하여 본 결과를 지지해준다. Park과 Park [22]은 이눌로프리바이오틱스 $300,450 \mathrm{ppm}$ 을 섭취한 브로일러에서 도체율, 다리살, 가슴살 무게 증가 및 복강지방이 대조구와 항생제 첨가구에 비해서 낮아짐을 보고하였으며 이는 본 실험 결과를 지지해준다.

\section{면역물질}

이눌로프리바이오틱스를 섭취한 브로일러의 혈청 면역물 질 및 면역기관 무게변화는 Table 4 에 나타냈다. 혈청 $\mathrm{IgG}$, $\mathrm{IgM}, \mathrm{IgA}$ 수준은 이눌로프리바이오틱스 첨가구가 대조구, 항 생제 첨가구와 비교할 때 유의하게 증가하였다. 한편, 이눌로 프리바이오틱스 $250 \mathrm{ppm}$ 첨가구는 이눌로프리바이오틱스 $200 \mathrm{ppm}$ 첨가구에 비해서 높았고 항생제 첨가구는 대조구에 비해서 높았으며 이들 처리구 간 통계적인 유의차 가 나타났 다. 혈청 $\mathrm{IgG}$ 증가율은 대조구와 비교할 때 이눌로프리바이오 틱스 $200 \mathrm{ppm}, 250 \mathrm{ppm}$ 첨가구에서 각각 155.6\%, 168.5\%,
항생제 첨가구와 비교할 때 이눌로프리바이오틱스 $200 \mathrm{ppm}$, $250 \mathrm{ppm}$ 첨가구에서 각각 $125.1 \%, 135.5 \%$ 로 나타났다. IgM은 대조구와 비교할 때 이눌로프리바이오틱스 $200 \mathrm{ppm}, 250$ $\mathrm{ppm}$ 첨가구에서 각각 $167.8 \%, 170.5 \%$, 항생제 첨가구와 비교 할 때 이눌로프리바이오틱스 $200 \mathrm{ppm}, 250 \mathrm{ppm}$ 첨가구에서 각각 $100.5 \%, 102.21 \%$ 증가하였다. IgA는 대조구와 비교할 때 이눌로프리바이오틱스 $200 \mathrm{ppm}, 250 \mathrm{ppm}$ 첨가구에서 각각 $125.3 \%, 105.9 \%$, 항생제 첨가구와 비교할 때 이눌로프리바이 오틱스 $200 \mathrm{ppm}, 250 \mathrm{ppm}$ 첨가구에서 각각 $121.9 \%, 103.0 \%$ 증가하였다.

이눌로프리바이오틱스를 섭취한 브로일러에서 혈청 $\operatorname{IgG}$ 가 높았던 점은 체액성면역 능력을 향상시키는 데 있어서 이눌로 프리바이오틱스의 효율성이 높았음을 의미한다[22]. 면역단백 질은 골수의 B-cell에서 만들어지며 가금에서 $\mathrm{IgG}, \mathrm{IgA}, \mathrm{IgM}$ 은 포유동물의 면역단백질과 생물학적 특성이 비슷하다. 혈액 $\mathrm{IgG}$ 의 농도는 가장 높고 생체면역력을 담당하므로 혈액 $\mathrm{IgG}$ 의 역가는 체액성면역의 지표가 된다[15]. 칠면조에게MOS를 급여하였을 때 혈청 $\mathrm{IgG}$ 가 증가하였다는 여러 연구자[21,31] 의 보고는 본 결과와 경향을 같이한다.

생체중에 대한 비율로서 나타낸 브로일러의 흥선과 $\mathrm{F}$ 낭 은 이눌로프리바이오틱스 첨가구가 대조구, 항생제 첨가구 에 비해서 유의하게 높았고 이눌로프리바이오틱스 200 $\mathrm{ppm}, 250 \mathrm{ppm}$ 사이의 통계적인 유의차는 없었으나 항생제 첨가구는 대조구에 비해서 유의하게 높았다. 비장은 이눌로 프리바이오틱스 $200 \mathrm{ppm}, 250 \mathrm{ppm}$, 항생제 첨가구가 서로 비슷하였으며 이러한 세 개의 처리구는 대조구와 비교할 때 유의하게 높았다.

흥선은 항체생산을 위한 중요한 기관으로써 여기에 제시한 흥선지수에 관한 자료는 이눌로프리바이오틱스가 브로일러 에서 흥선세포의 증식능력을 증가시켰음을 시사해준다. 닭의 면역체계는 흰쥐, 생쥐와 같은 포유동물과 약간 차이가 있다. $\mathrm{F}$ 낭은 가금에서 일정한 편이며 B-림프구(B-lymphocyte)의 발 달 및 기능적인 성숙연구에 사용되었다. 닭이 성숙하면서 흥 선과 F낭이 발달하고 이와 함께 닭의 면역반응은 비장과 림프

Table 4. Indices of main immune organs and immunogloblin of 35 days old broilers fed inuloprebiotics-supplemented diets

\begin{tabular}{lccccc}
\hline & \multicolumn{5}{c}{ Treatment groups } \\
\cline { 2 - 5 } Parameter $^{1)}$ & Control & $\begin{array}{c}\text { Antibiotics } \\
8 \mathrm{ppm}\end{array}$ & $\begin{array}{c}\text { Inuloprebiotics } \\
200 \mathrm{ppm}\end{array}$ & $\begin{array}{c}\text { Inuloprebiotics } \\
250 \mathrm{ppm}^{\mathrm{a}}\end{array}$ & SEM $^{2)}$ \\
\hline $\mathrm{IgG}, \mu \mathrm{g} / \mathrm{ml}$ & $65.51^{\mathrm{d}}$ & $79.67^{\mathrm{c}}$ & $96.54^{\mathrm{b}}$ & $103.67^{\mathrm{a}}$ & 4.4887 \\
$\mathrm{IgM}, \mu \mathrm{g} / \mathrm{ml}$ & $40.17^{\mathrm{d}}$ & $63.27^{\mathrm{c}}$ & $64.56^{\mathrm{b}}$ & $65.38^{\mathrm{a}}$ & 2.7369 \\
$\mathrm{IgA}, \mu \mathrm{g} / \mathrm{ml}$ & $38.01^{\mathrm{d}}$ & $43.28^{\mathrm{c}}$ & $45.63^{\mathrm{a}}$ & $44.14^{\mathrm{b}}$ & 0.8314 \\
Thymus & $0.09^{\mathrm{c}}$ & $0.15^{\mathrm{b}}$ & $0.20^{\mathrm{a}}$ & $0.19^{\mathrm{a}}$ & 0.0136 \\
Spleen & $1.05^{\mathrm{b}}$ & $1.49^{\mathrm{a}}$ & $1.58^{\mathrm{a}}$ & $1.59^{\mathrm{a}}$ & 0.0582 \\
Bursa of Fabricius & $1.90^{\mathrm{c}}$ & $2.40^{\mathrm{b}}$ & $2.68^{\mathrm{a}}$ & $2.80^{\mathrm{a}}$ & 0.1094 \\
\hline
\end{tabular}

${ }^{1)}$ Organ weight: $\mathrm{g} / \mathrm{kg}$ live body weight.

${ }^{2)}$ Standard error of the mean values.

${ }_{a, b, c, d}$ Mean values with different superscripts differ significantly $(p<0.05)$. 
절에 의존하게 된다. 닭의 면역상태의 조절은 동물의 건강에 유익한 효과를 나타낼 수 있으며 생산성을 증가시키는 효과를 기대할 수 있다[35,38]. 닭에서 면역단백질은 $\operatorname{IgM}$ 을 $\mathrm{IgG}$ 로 전 환하는 기작 또는 $\mathrm{IgA}$ 를 성공적으로 작용시키는데 필수적인 $\mathrm{F}$ 낭, 기타 연관된 림프기관 및 흥선에 의존하고 있다[1]. 따라 서 면역단백질을 함유하는 세포생산의 증가 및 높아진 혈액 면역단백질의 농도는 이눌로프리바이오틱스를 섭취한 닭에 서 발견된 림프기관의 회귀결과일 것으로 볼 수 있다. Zhang 등[41]은 이소말토올리고당을 섭취한 브로일러에서 흥선지수 가 유의적으로 증가하였다고 했으며 이는 본 연구결과와 맥락 을 같이한다.

\section{맹장 미생물 변화}

이눌로프리바이오틱스를 섭취한 브로일러의 맹장 내용물 에서 조사한 미생물의 변화는 Table 5 에 나타냈다. 장 내 유익 한 미생물로 알려진 Bifidobacteria와 Lactobacillus는 이눌로프 리바이오틱스 첨가구가 대조구, 항생제 첨가구에 비해서 유의 하게 높았다. 유해한 미생물로 알려진 E. coli와 Salmonella는 이눌로프리바이오틱스 첨가구가 대조구, 항생제 첨가구와 비 교할 때 유의하게 낮았다.

이눌로프리바이오틱스를 섭취한 이눌로프리바이오틱스 첨 가구에서 맹장 내 Lactic acid bacteria와 Bifidobacteria 균수가 높았던 점은 미세캡슐화에 의해 제조된 이눌로프리바이오틱 스가 브로일러의 위와 소장을 우회함으로써 이눌린의 분해율 과 흡수율이 낮아짐과 동시에 대부분이 맹장으로 이동하게 되고 궁극적으로 맹장에서 용해된 이눌린이 Lactic acid bacteria와 Bifidobacteria의 성장을 위한 기질로서 더욱더 활용되 었을 것으로 생각할 수 있다 $[13,22]$. 프리바이오틱스로서 이눌 린, 올리고당 및 올리고당과 관련한 탄수화물은 동물의 소장 에서 분해되지 않고 $80 \%$ 이상이 대장까지 도달하여 유해한 미생물인 Escherichia coli, Salmonella와 Campylobacter의 균수 를 낮추고 유익한 Bifidobacteria의 선택적인 증식을 높이는 비피더스균 활성효과를 갖는 것으로 알려져 있다[11,12]. Rebolé 등[28]과 Rada 등[27]은 브로일러 및 산란계에게 이눌 린을 급여하였을 때 맹장의 Bifidobacteria에 있어서 유의적인
증가를 보고하여 본 결과를 지지해준다.

소화관에서 미생물의 중요성은 장 상피세포에 필요한 에너 지를 공급해주는 발효산물의 합성에 있어서 장 미생물의 역 할, 소화관 면역체계의 자극, 비타민 $\mathrm{K}$ 의 합성 그리고 외인성 병원성 세균의 군락화에 대한 저항성을 나타내는 것이다[33]. Lactobacillus와 Bifido bacteria는 동물의 건강에서 유익한 미생 물로써 잘 알려져 있으며, E. coli, Clostridium perfrigens와 같은 기타 미생물은 유해할 수 있다[5]. Bifidobacteria, Lactobacillus 의 장 내 균총은 영양소와 장 부착부위에 대하여 잠재적인 병원체와 경쟁하고 있기 때문에 장 내 병원균 집단을 낮춘다. 또한, Bifidobacteria, Lactobacillus는 E. coli에 대하여 활성적인 물질의 박테리오신(bacteriocin)을 분비하며 Bifidobacteria는 유기산과 기타 미생물에 대한 기질을 생성한다. Lactobacillus 의 발효로부터 생성된 대부분의 유기산은 젖산과 초산이다. 이러한 모든 기질은 병원균에 의한 장 군락화를 억압할 수 있다 $[11,29,40]$. 이눌로프리바이오틱스 처리구에서 나타난 맹 장 E. coli, Salmonella 균수가 유의하게 낮아진 이유는 바로 이 러한 기전의 일부라고 생각할 수 있다. $\mathrm{Xu}$ 등[38]은 브로일러 에게 프럭토올리고당을 함유하는 사료를 급여했을 때, 프럭토 올리고당 첨가구의 맹장 내용물에서 총혐기성균과 Bifidobacteria, Lactobacillus 균수는 유의하게 증가하였으나, E. coli 균수는 유의하게 감소를 나타냈다고 하였으며 본 결과 는 이들의 보고와 맥락을 같이하고 있다. 닭에서 Salmonella 군락화의 주요 장소는 맹장이며 Salmonella는 병아리에서 설사 및 심각한 체중손실과 같은 살모넬라 감염증을 일으킨다는 점은 널리 알려져 있는 사실이다. 이눌로프리바이오틱스를 섭 취한 브로일러에서 E. coli와 Salmonella가 낮아진 점은 맹장 내 존재하는 Bifidobacteria, Lactobacillus가 유의하게 높아진 점과 관련이 있다.

본 연구결과 이눌로프리바이오틱스를 섭취한 브로일러의 맹장내용물에서 건강을 증진시키는 Bifidobacteria, Lactobacillus 균의 성장을 선택적으로 자극하는 효과가 나타났 으며 이익이 되지 않거나 또는 유해한 병원체 E. coli, Salmonella의 증식을 억제하는 것으로 나타났다. 또한, 항생제 첨가구 및 대조구와 비교해 볼 때, 이눌로프리바이오틱스 처

Table 5. Viable cell counts of microflora in cecal digesta of broilers fed the experimental diets for 35 days

$(\log 10 \mathrm{cfu} / \mathrm{g}$ content)

\begin{tabular}{lccccc}
\hline & \multicolumn{5}{c}{ Treatment groups } \\
\cline { 2 - 5 } Item & Control & $\begin{array}{c}\text { Antibiotics } \\
8 \mathrm{ppm}\end{array}$ & $\begin{array}{c}\text { Inuloprebiotics } \\
200 \mathrm{ppm}\end{array}$ & $\begin{array}{c}\text { Inuloprebiotics } \\
250 \mathrm{ppm}^{1)}\end{array}$ & \\
\hline Bifidobacteria & $6.07^{\mathrm{d}}$ & $7.21^{\mathrm{c}}$ & $8.53^{\mathrm{b}}$ & $8.63^{\mathrm{a}}$ & 0.2599 \\
Lactobacillus & $6.81^{\mathrm{c}}$ & $7.77^{\mathrm{b}}$ & $8.55^{\mathrm{a}}$ & $8.92^{\mathrm{a}}$ & 0.2115 \\
E. coli & $8.95^{\mathrm{a}}$ & $7.84^{\mathrm{b}}$ & $6.36^{\mathrm{c}}$ & $6.65^{\mathrm{c}}$ & 0.2491 \\
Salmonella & $8.78^{\mathrm{a}}$ & $7.63^{\mathrm{b}}$ & $6.30^{\mathrm{c}}$ & $6.34^{\mathrm{c}}$ & 0.3167 \\
\hline
\end{tabular}

${ }^{1)}$ Standard error of the mean values.

${ }^{a, b, c, d}$ Mean values with different superscripts differ significantly $(p<0.05)$. 
리구의 맹장에서 건강에 유익한 Lactobacillus와 Bifidobacteria 의 성장이 촉진되었고, 면역기관의 무게가 증가된 점(Table 4)으로 보아서 이눌로프리바이오틱스가 병아리의 설사를 예 방하고 성장을 촉진할 수 있는 항균성장촉진제로서 잠재성을 갖는 것으로 사료된다[17,22].

결론적으로, 브로일러 사료 내 이눌로프리바이오틱스 200 $\mathrm{ppm}$ 수준은 항생제 첨가구 및 대조구에 비해서 맹장 미생물 의 유익균 Bifidobacteria, Lactobacillus의 집단을 선택적으로 증가시켰고, 유해균 E. coli, Salmonella의 균수 감소를 확인할 수 있었다. 또한, 주요 면역기관인 흥선, 비장 및 $\mathrm{F}$ 낭세포의 증식능력을 자극함으로써 혈액 면역단백질의 농도를 높여주 어 동물의 건강을 향상시키고 성장능력을 촉진할 수 있음을 확인하였다.

\section{감사의 글}

본 연구는 태화사초사료(주)의 2007년도 연구비지원으로 이루어졌으며, 김겸헌, 박상오, 조미영 학생, 동물실험 및 기기 분석에 도움을 준 강원대학교 동물자원공동연구소에 감사를 드립니다.

\section{References}

1. Bienenstock, J., J. Gauldie, and D. Y. E. Perey. 1973. Synthesis of $\operatorname{IgG}, \operatorname{IgA}$, IgM by chicken tissues: Immunofluorescent and $14 \mathrm{C}$ amino acid incorporation studies. J. Immun. 111, 1112-1118.

2. Cetein, N., B. K. Guclu, and E. Cetein. 2005. The effect of prebiotics and mannan-oligosaccharide on some hematological and immunological parameters in turkey. J. Vet. Med A. 52, 263-267.

3. Close, B., K. Banister, V. Baumans, E. M. Bernoth, N. Bromage, J. Bunyan, W. Erhardt, P. Flecknell, N. Gregory, H. Hackbarth, D. Morton, and C. Warwick. 1997. Recommendations for euthanasia of experimental animals, Part 2. Laboratory Animals 31, 1-32.

4. Davidson, M. H., K. C. Maki, C. Specks, S. A. Too, and K. B. Crennan. 1998. Effects of dietary inulin on serum lipids in men and women with hypercholesterolemia. Nutr. Res. 18, 503-517.

5. Devaraj, S., S. Vega-Lopez, N. Kaul, F. Schonlau, P. Rohdewald, and I. Jialal. 2002. Supplementation with a pine bark extract rich in polyphenols increases plasma antioxidant capacity and alters the plasma lipoprotein profile. Lipids 37, 931-934.

6. Dibner, J. J. and J. D. Richards. 2005. Antibiotic growth promoters in agriculture: History and mode of action. Poult. Sci. 84, 634-643.

7. Dorotea, L. M. and D. N. M. Maris. 2005. Molecular properties and prebiotic effect of inulin obtained from artichoke
(Cynara scolymus L.). Phytochemistry 66, 1476-1484.

8. Fiordaliso, M., N. Kok, J. P. Desager, F. Goethals, D. Deboyser, R. Marcel, and D. Nathalie. 1995. Dietary oligofructose lowers triglycerides, phospholipids and cholesterol in serum and very low density lipoproteins of rats. Lipids 30, 163-167.

9. French, A. D. 1989. Chemical and physical properties of fructans. Plant Physiol. 134, 125-136.

10. Gibson, G. R. and R. A. Rastall. 2006. Prebiotics: Development and application. John Wiley and Sons, Ltd., USA.

11. Gibson, G. R. and X. Wang. 1994. Bifidogenic properties of different types of fructooligosaccharides. Food Microbiol. 11, 491-498.

12. Gibson, G. R., E. R. Bead, X. Wang, and J. H. Cummings. 1995. Selective stimulation of bifidobacteria in the human colon by oligofluctose and inulin. Gastroenterology 108, 975982.

13. Gong, J., R. J. Forster, H. Yu., J. R. Chambers, P. M. Sabour, R. Wheatcroft, and S. Chen. 2002. Diversity and phylogenetic analysis of bacteria in the mucosa of chicken ceca and comparison with bacteria in the cecal lumen. FEMS Microbiol. Lett. 208, 1-7.

14. Hernandez, F., J. Madrid, V. Garcia, J. Orengo, and M. D. Megias. 2004. Influence of two plant extracts on broilers performance, digestibility, and digestive organ size. Poult. Sci. 83, 169-194.

15. Higgins, D. A. 1975. Physical and chemical properties of fowl immunoglobulins. Vet. Bull. 45, 139-154.

16. Kok, N., M. Roberfroid, A. Robert, and N. Delzenne. 1996. Involvement of lipogenesis in the lower VLDL secretion induced by oligofructose in rats. Br. J. Nutr. 76, 881-890.

17. Modler, H. W., R. C. Mckellar, and M. Yaguchi. 1990. Bifidobacteria and bifidogenic factors. Can. Inst. Food Sci. Technol. J. 23, 29-41.

18. Mockett, A. P. A. and M. E. Rose. 2007. Immune responses to eimeria: quantification of antibody isotypes to Eimeria tenella in chicken serum and bile by means of the ELISA. Parasite Immunol. 8, 481-489.

19. Munoa, F. J. and R. Pares. 1988. Selective medium for isolation and enumeration of bifidobacterium SPP. Appl. Environ. Microbiol. 54, 1715-1718.

20. National Research Council. 1994. Nutrients requirements of poultry. 9th rev. National Academy Press, Washington DC. USA.

21. Park, S. O., J. H. Shin, W. K. Choi, and B. S. Park. 2010. Antibacterial activity of house fly-maggot extracts against MRSA(Methicillin-restante Staphylococcus aureus) and VRE(Vancomycin restrant enterococci). J. Environ. Biol. 31, 865-871.

22. Park, B. S. 2008. Bifidogenic effects of inuloprebiotics in broiler chickens. J. Life. Sci. 18, 1693-1699.

23. Park, S. O. and B. S. Park. 2009. Effect of dietary inuloprebiotics on performance, serum immunoglobulin and caecal microflora in broiler chickens. Korean J. Organic Agric. 17, 539-555. 
24. Park, B. S. and D. H. Son. 2008. Feed composition for replacing antibiotic comprising inulin originated from jerusalem artichoke. WIPO Patent Application WO/2008/075878.

25. Patterson, J. A. and K. M. Burkholder. 2003. Application of prebiotics and probiotics in poultry production. Poult. Sci. 82, 627-631.

26. Rehman, H., P. Hellweg, D. Taras, and J. Zentek. 2008. Effects of dietary inulin on the intestinal short chain fatty acids and microbial ecology in broiler chickens as revealed by denaturing gradient gel electrophoresis. Poult. Sci. 87, 783-789.

27. Rada, V., D. Duskova, M. Marounek, and J. Petr. 2001. Enrichment of Bifidobacteria in the hen caeca by dietary inulin. Folia Microbiol. 46, 73-75.

28. Rebolé, A., L. T. Ortiz, M. L. Rodríguez, C. Alzueta, J. Treviño, and S. Velasco. 2010. Effects of inulin and enzyme complex, individually or in combination, on growth performance, intestinal microflora, cecal fermentation characteristics, and jejunal histomorphology in broiler chickens fed a wheat- and barley-based diet. Poult. Sci. 89, 276-286.

29. Rolfe, R. D. 2002. The role of probiotic cultures in the control of gastrointestinal health. J. Nutr. 130, 396S-402S.

30. SAS. 2005. Statistical Analysis System Institute Inc. JMP. Statistical Discovery. V. 6.0.

31. Savage, T. F., P. F. Cotter, and E. I. Zakrzewska. 1996. The effect of feeding of a mannan oligosaccharide on immunoglobulin plasma IgG and bile IgA of Wrolstad MW male turkey. Poult. Sci. 75, 143.

32. Scot PIL training manual. 1994. Glasgow Univ. UK.

33. Shakibaie, M. R., K. A. Jalilzadeh, and S. M. Yamakanamardi. 2009. Horizontal transfer of antibiotic resistance gene among gram negative bacteria in sewage and lake water and influence of some physico-chemical parameters of water on conjugation process. J. Environ. Biol. 30, 45-49.
34. Tako, E., R. P. Glahn, R. M. Welch, X. Lei, K. Yasuda, and D. D. Miller. 2008. Dietary inulin affects the expression of intestinal enterocyte iron transporters, receptors and storage protein and alters the microbiota in the pig intestine. Br. J. Nutr. 99, 472-480.

35. Tizard, B. 2002. The avian antibody response. Seminars in Avian and Exotic Pet Medicine. 11, 2-14.

36. Tokunaga, T., T. Oku, and N. Hosoya. 1986. Influence of chronic intake of new weetener fructooligosaccharide (Neosugar) on growth and gastrointestinal function of the rat. J. Nutr. Sci. Vitaminol. 32, 111-121.

37. Velasco, S., L. T. Ortiz, C. Alzueta, A. Rebolé, J. Treviño, and M. L. Rodríguez. 2010. Effect of inulin supplementation and dietary fat source on performance, blood serum metabolites, liver lipids, abdominal fat deposition, and tissue fatty acid composition in broiler chickens. Poult. Sci. 89, 1651-1662.

38. Wang, Y. W., C. J. Field, and J. S. Sim. 2000. Dietary polyunsaturated fatty acids alter lymphocyte subset proportion and proliferation, serum immunoglobulin G concentration, and immune tissue development in chicks. Poult. Sci. 79, 1742-1748.

39. Xu, Z. R., C. H. Hu, M. S. Xia, X. A. Zhan, and M. Q. Wang. 2003. Effects of dietary fructooligosaccharide on digestive enzyme activies, intestinal microflora and morphology of male broilers. Poult. Sci. 82, 1030-1036.

40. Xu, Z. R., C. H. Hu, and M. O. Wang. 2002. Effects of fructooligosaccharide on conversion of L-tryptophan to skatole and indole by mixed populations of pig fecal bacteria. J. Gen. Appl. Microbiol. 48, 83-89.

41. Zhang, W. F., D. F. Li, W. Q. Lu, and G. F. Yi. 2003. Effects of isomalto-oilgosaccharides on roiler performance and intestinal microflora. Poult. Sci. 82, 657-663. 


\section{초록 : 육계의 성장능력 향상을 위한 이눌로프리바이오틱스의 적정 첨가수준 결정}

\section{박병성*}

(강원대학교 동물생명공학과)

본 연구는 브로일러의 성장능력을 촉진하기 위한 사료 내 이눌로프리바이오틱스의 적정 첨가수준을 결정하기 위하여 수행하였다. 부화 당일 로스계통(Ross 308)의 브로일러 수컷 320수를 4 개의 처리구로 완전임의배치하여 35 일 동안 사육하였다. 실험처리구는 대조구(무첨가구), 항생제 첨가구(avilamycin $8 \mathrm{ppm}$ ), 이눌로프리바이오틱 스 $200 \mathrm{ppm}$ 첨가구 및 이눌로프리바이오틱스 $250 \mathrm{ppm}$ 첨가구로 구분하였다. 브로일러의 체중과 사료섭취량은 두개의 이눌로프리바이오틱스 첨가구가 대조구, 항생제 첨가구 보다도 높았고, 항생제 첨가구는 대조구에 비해서 높았으며 통계적인 유의차가 인정되었다. 전체 실험기간 동안 사료요구율은 대조구가 이눌로프리바이오틱스 첨 가구와 비교할 때 유의하게 높았으나 항생제 첨가구와 이눌로프리바이오틱스 첨가구 사이의 통계적인 유의차는 없었다. 도체중, 도체율, 가슴살, 다리살의 무게는 이눌로프리바이오틱스 첨가구가 대조구, 항생제 첨가구에 비해 서 유의하게 높았고, 이눌로프리바이오틱스 $200 \mathrm{ppm}, 250 \mathrm{ppm}$ 첨가구 사이의 차이는 없었으나 항생제 첨가구는 대조구에 비해서 유의하게 높았다. 복강지방은 이눌로프리바이오틱스 첨가구가 유의하게 감소(19.08 23.30\%)하 였으며 혈액 면역물질과 흥선, $\mathrm{F}$ 낭의 무게는 이눌로프리바이오틱스 첨가구가 대조구와 항생제 첨가구에 비해서 유의하게 증가하였다. 장내 유익한 Bifidobacteria와 Lactobacillu는 이눌로프리바이오틱스 첨가구가 대조구와 항생 제 첨가구에 비해서 유의하게 증가하였으나 유해한 E. coli와 Salmonella는 그 반대로 나타났으며 통계적인 유의차 가 인정되었다. 본 연구는 브로일러의 성장능력 향상을 위한 사료 내 이눌로프리바이오틱스의 적정 첨가수준은 $200 \mathrm{ppm}$ 에서 결정될 수 있음을 보여준다. 